\title{
Morphological and Cultural Characteristics of Different Collections of Medicinal White-Rot Bracket Fungi Ganoderma P. Karst
}

\author{
Anjali Suansia* and Priya John \\ Department of Plant Pathology, N. M. college of Agriculture, Navsari Agricultural University, \\ Navsari-396450, India \\ *Corresponding author
}

\section{A B S T R A C T}

Ganoderma is widely distributed mushroom with the longest record of medicinal use. Specimens of Ganoderma were collected from several locations in Navsari.

\section{Keywords}

Ganoderma,

Medicinal

mushroom,

Morphology,

Cultural characters,

Basidiocarp

Article Info

Accepted:

20 December 2019

Available Online:

20 January 2020
These were identified on the basis of macroscopic and microscopic traits of fruiting bodies and biological properties of pure cultures. A total of seven Ganoderma isolates were collected and named based on genus, place and locality. These were GNN-1, GNN-2, GNN-3, GND-1, GND-2, GNG-1 and GNG-2. The shape of basidiocarp varied from auriform to discoid, colour from light to dark brown; they were either sessile or stipitate with double walled ellipsoid brown coloured basidiospores and pore layers were white or brownish white coloured. The colour of mycelia varied from white to off white colour and density varied from cottony to velvety. Thick walled and elliptical to spherical shaped chlamydospores found in four isolates and the position was varied from terminal to intercalary. The maximum growth was recorded in Mushroom Complete Medium (MCM) media viz., $7.20 \mathrm{~cm}, 6.67 \mathrm{~cm}, 6.63 \mathrm{~cm}$ and $5.97 \mathrm{~cm}$ in $\mathrm{GNN}-2$, GNG-1, GND-1 and GNN-1, respectively on fifth day of inoculation. Mycelial growth of GNN-2 was significantly more as compared to rest of the isolates which covered the petriplate earlier to all i.e. on sixth day.

\section{Introduction}

Ganoderma P. Krast is one of the most popular mushrooms in oriental medicine. It is found in tropical, sub-tropical, and temperate climates all around the world but prefers warmer climate on a large variety of trees such as deciduous and hardwood trees. The diverse climatic condition in India made the country a natural habitat for Ganoderma. This is probably the first medicinal mushroom to gain importance in India. The genus Ganoderma is identified on the basis of their basidiocarp morphology, microscopic view of basidiospore and mycelium. Ganoderma are fairly large with a generally tough bracket like pileus (cap) that can reach more than 60 cm (24 inches) in diameter. Many species have a stipe (stalk) to support the pileus, some species are sessile and have a pileus attached 
directly to the tree or dead stump or log. The pileus can be white, yellow, brown, red, or deep purple, often with a light-coloured border, though coloration patterns within species can vary depending on age and environmental conditions. They develop a bright, white, outer growth margin while growing. As growth continues, the margin may begin to change color and develop a tough skin that has a shiny lacquered appearance in many species. It is characterized by the presence of pores instead of the gills on the lower side of the fruiting body (Wang et al., 2012, Kapoor and Sharma, 2014, Nithya et al., 2014 and Rajesh et al., 2014). Macro- and microscopic features of these Ganoderma basidiocarps are well investigated, but only a few data are available on their cultivation in vitro (Woo-Sik et al., 2009, Badalyan et al., 2015). Pure cultures of Ganoderma offer important taxonomic features and can be used in biotechnology and biomedicine (Balaes and Tanase, 2012, Badalyan et al., 2015). In addition, some molecular analyzes for identification are only possible with the use of pure cultures - e.g. MALDI-TOF MS (Pristas et al., 2017). Thus, we would like to contribute to knowledge of the mycelial characteristics of Ganoderma species along with the morphological characteristics. Thus, the aim of this study is to describe the macroand microscopic characterstics of fruiting bodies as well as biological properties of pure cultures (color, shape, texture of the colonies) along with growth rate of mycelium of Ganoderma species.

\section{Materials and Methods}

Morphological characterization of Ganoderma isolates

Survey was carried out during June 2018 to September 2018 for collection of naturally growing Ganoderma at several locations of Navsari viz., Navsari Agricultural University campus, Dandi and Gandevi. Collected samples were named based on genus, place and locality. These are GNN-1, GNN-2 and GNN-3 were collected from Navsari Agricultural University campus, GND-1 and GND- 2 two were from Dandi and GNG-1 and GNG-2 two were from Gandevi. They were identified on the basis of macroscopic traits viz., shape, size and colour of pileus, presence or absence of stipe, colour and length of stipe and microscopic traits viz., size and shape of basidiospores.

\section{Isolation of Ganoderma mycelium}

The collected specimens were isolated using tissue culture technique (Kapoor and Sharma, 2014).Small pieces of basidiocarp (1-2 mm) were cut and surface sterilised with 0.1 per cent mercuric chloride solution for 10 to 20 seconds and plated on potato dextrose agar (PDA) and malt extract agar (MEA) media in Petri plates. Visible mycelia grown from the pieces of basidiocarp were subcultured onto fresh MEA media in Petri plates.

\section{Diametric growth of different Ganoderma isolates on different media}

Five different media viz., Potato Dextrose Agar (PDA), Malt Extract Agar (MEA), Tryptone Glucose Extract Agar (TGEA), Yeast Malt Extract Agar (YMEA) and Mushroom Complete Medium (MCM) were taken to study the mycelial growth pattern of Ganoderma. Actively growing culture plates of Ganoderma mycelium was punched at the advancing edge with a cork borer. A $5 \mathrm{~mm}$ diameter disc of the mycelium was then transferred into petri plates containing $20 \mathrm{ml}$ of each medium and placed at the centre of petri plates.

\section{Statistical Analysis}

The data was analysed using CRD and the difference among mean value was tested by 
using critical differences (CD) values at 5\% level of probability.

\section{Results and Discussion}

\section{Morphological characterization of Ganoderma isolates}

A total of seven Ganoderma isolates were collected from Navsari region during rainy season. Out of the seven isolates, three were collected from Navsari Agricultural University campus named as GNN-1, GNN-2 and GNN3 , two were procured from Dandi named as GND-1 and GND- 2 and another two were from Gandevi named as GNG-1 and GNG-2. The isolates were named based on genus, place and locality. GNN-1, GNN-2 and GND1 were found on dead stumps of unknown trees and two isolates GNN-3 and GNG-2 were on soil surface. While rest of the two isolates GND-1 and GNG-1 were found on the stem of Pink shower, Cassia grandis. The morphological characteristics varied among the basidiocarp collected within the same locality as well as between the three localities. The morphological features of seven Ganoderma isolates are listed in Table 1.

The size, shape (bud shape to discoid or auriform) and colour (white to golden brown or dark brown) of fruiting bodies of seven Ganoderma isolates varied with the growth stages. The basidiocarps were either sessile or stipitate. White or brownish white coloured pore layer was found beneath the pileus. Basidiospores were double walled ellipsoid brown in colour and the size varied from $8.7 \mathrm{x}$ 5.3 to $10.7 \times 7.1 \mu \mathrm{m}$. Reddish brown coloured spore print was obtained from isolate GNN-3. The present result supports the reports of Latiffah and Ho (2005), who studied the morphological characteristics of Ganoderma and identified the collected samples based on the morphological characters like habitat, shape, size and colour of pileus, size of stipe, shape and size of basidiospore and pore structure. Smith and Sivasithamparam (2003), who studied the morphological characters of Ganoderma and observed that basidiocarps were sessile, dimidate, semicircular or irregular. It typically varies from $5-50 \mathrm{~cm}$ wide and colour light brown to dark brown. Margins were white while growing, but same colour as crust or occasionally brownish black in older specimens. Pores were pale yellow or orange ageing to dark brown. Basidiospores were truncate to elliptic and 9.1-11.8 $\mu \mathrm{m} \mathrm{x}$ $5.5-9.1 \mu \mathrm{m}$ in size.

\section{Cultural Characteristics}

The cultural characteristics of seven Ganoderma isolates are listed in Table 2. The colour of mycelia varied from white to off white colour and density of mycelia varied from cottony to velvety. Isolates GNN-2, GNN-3, GND-1, GNG-1 and GNG-2 showed white whereas GNN-1 and GND-2 showed off white colour mycelia. Chlamydospores were thick walled, elliptical to spherical in shape and position varied from terminal to intercalary. Out of seven isolates, four isolates of Ganoderma (GNN-1, GNN-2, GND-1 and GNG-1) were selected on the basis of their fast growing nature on MEA for further study on the effect of five different media on the radial growth of mycelim on petri plates.

\section{Diametric growth of different Ganoderma isolates on different media}

The diametric growth patterns of four Ganoderma isolastes were listed in Fig. 1.

Isolate GNN-1: It showed off white coloured mycelia with yellow pigmentation and less denser in the centre on petri plates containing PDA while uniformly scattered on rest four media and bead like structures formed on petri plates and scanty and thin mycelia layer formed on TGEA. 
Fig.1 Mycelial growth of Ganoderma isolates on different media

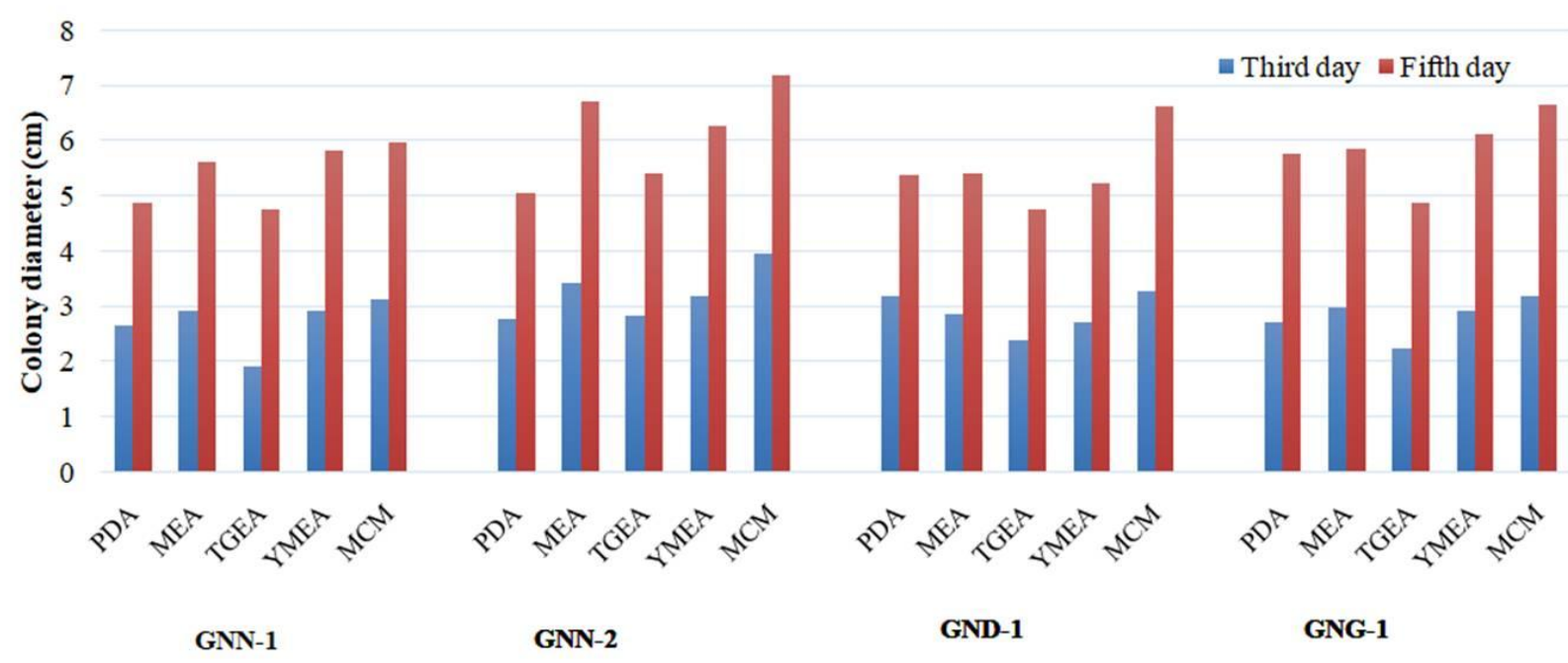

Fig.2 Different growth stages of Ganoderma isolates
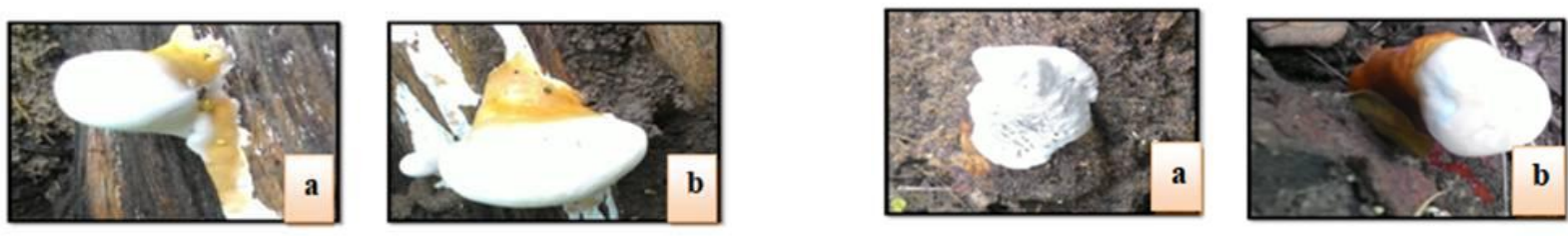
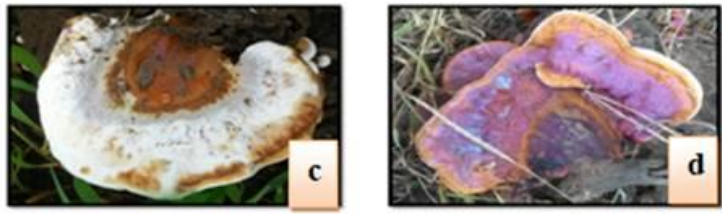

GNN-1
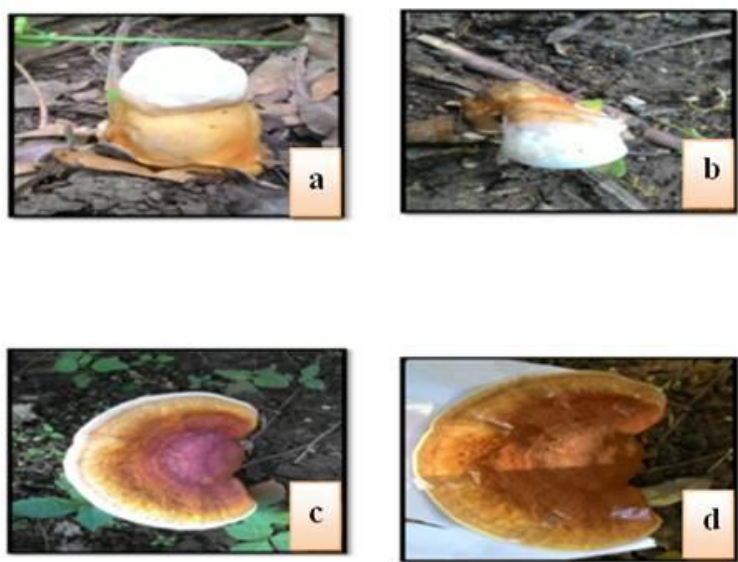

GNN-3
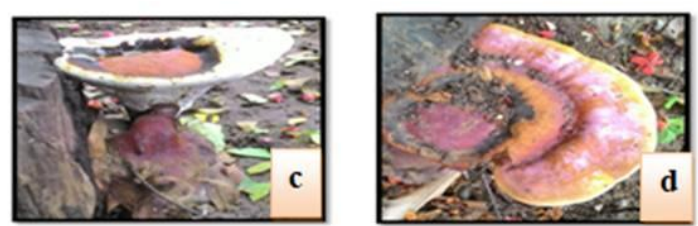

GNN-2
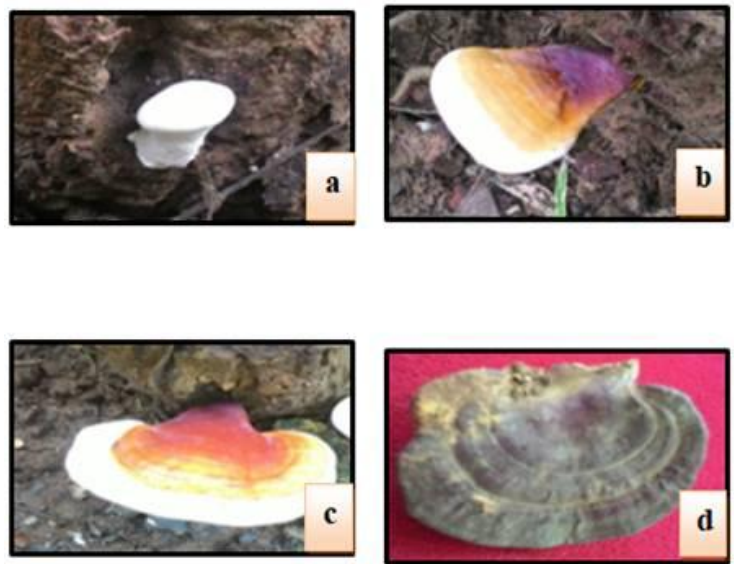

GND-1 

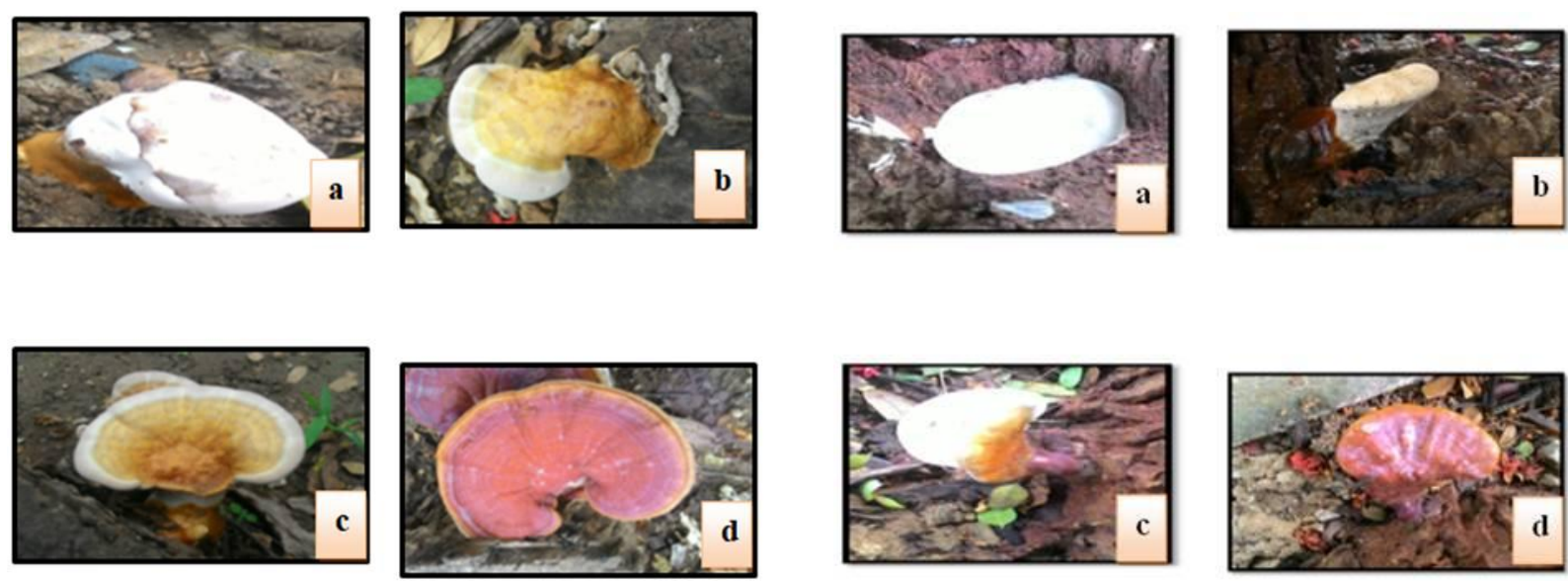

GND-2

GNG-1
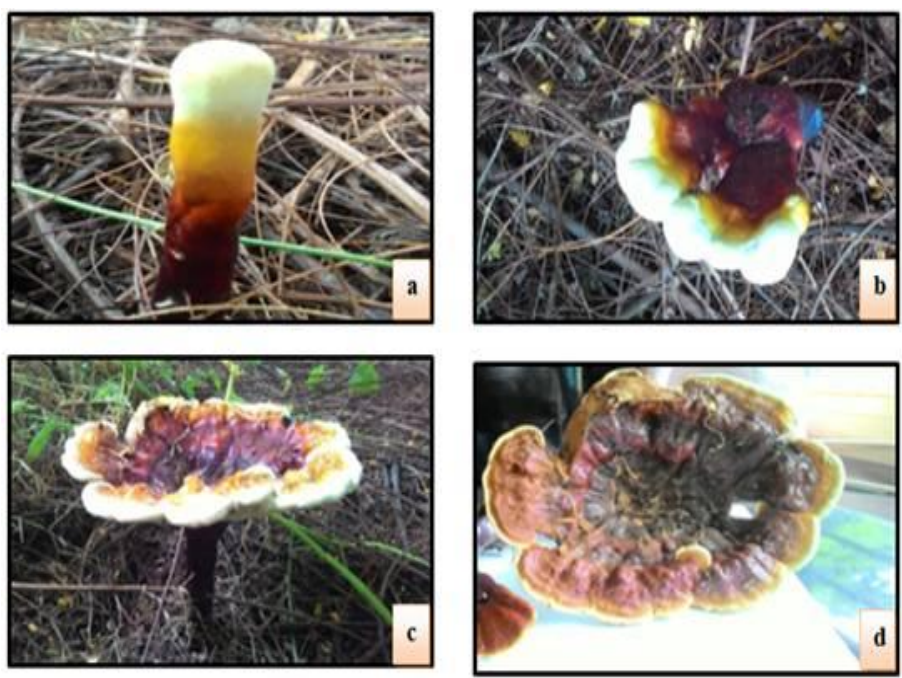

GNG-2

a. Primordia formation, b. Elongation of primordial, c. Flattening and thickening of cap, d. Maturation of cap

Fig.3 Pore layer and basidiospores
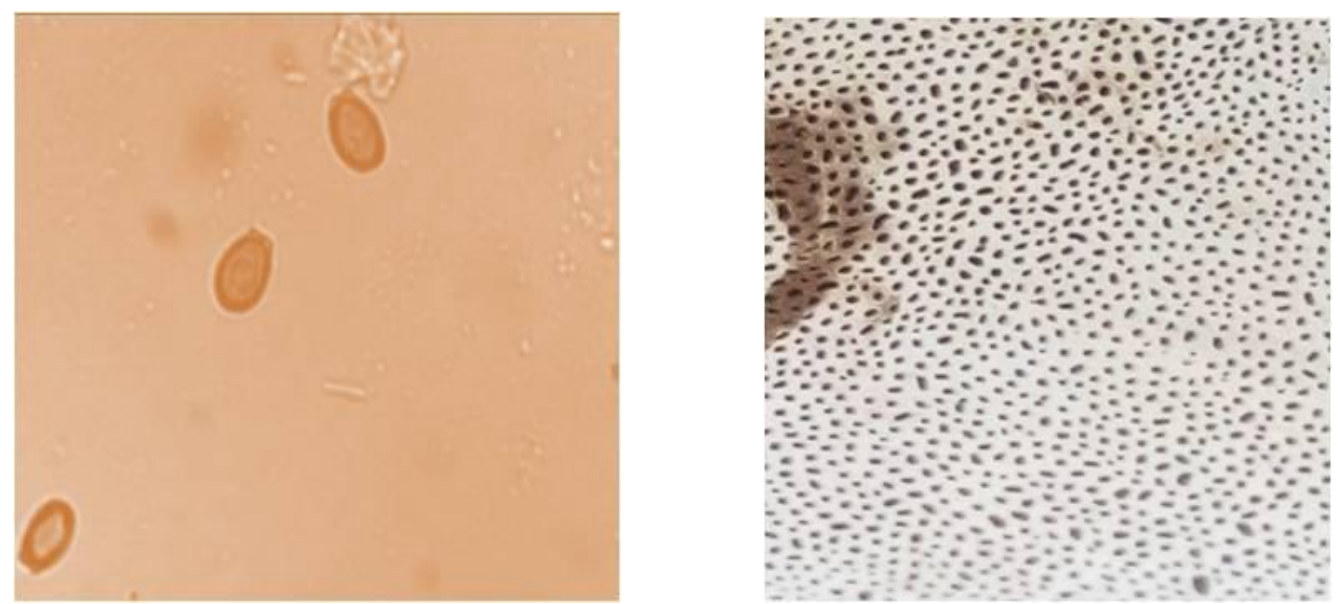
Int.J.Curr.Microbiol.App.Sci (2020) 9(1): 2636-2644

Fig.4 Mycelial growth of Ganoderma isolates

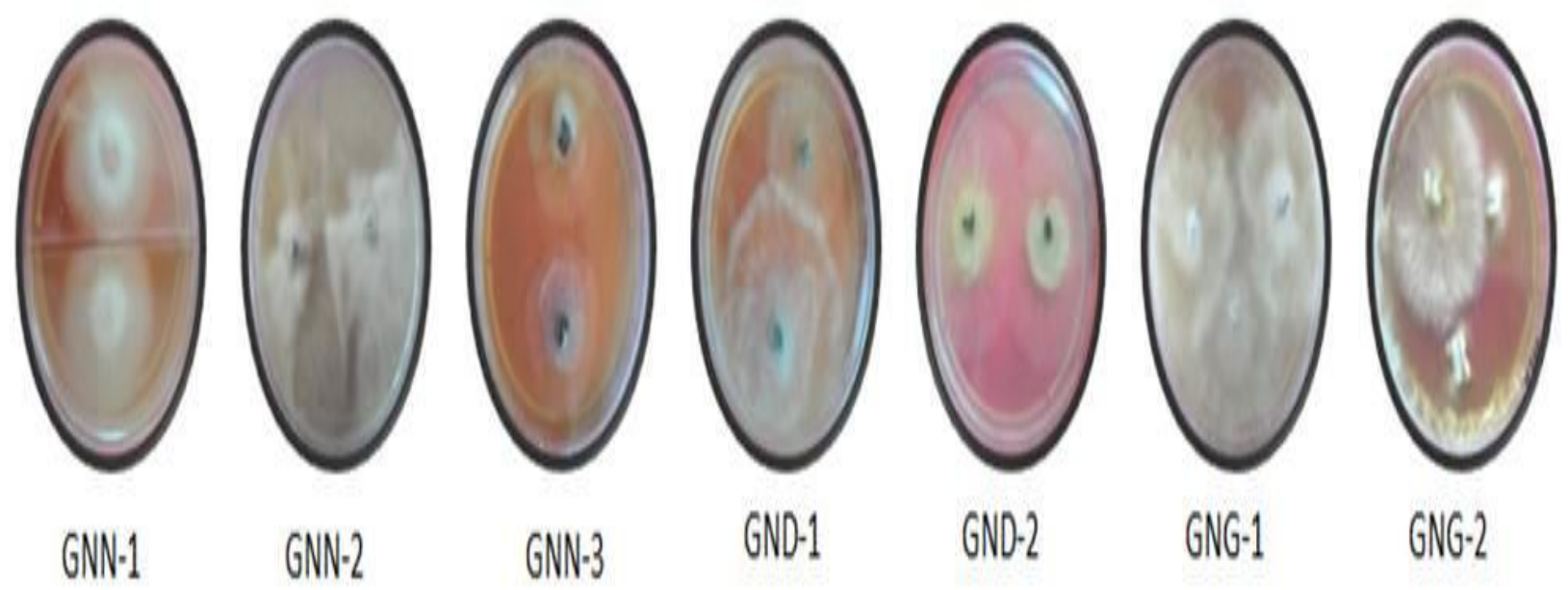

Plate.4 Chlamydospores

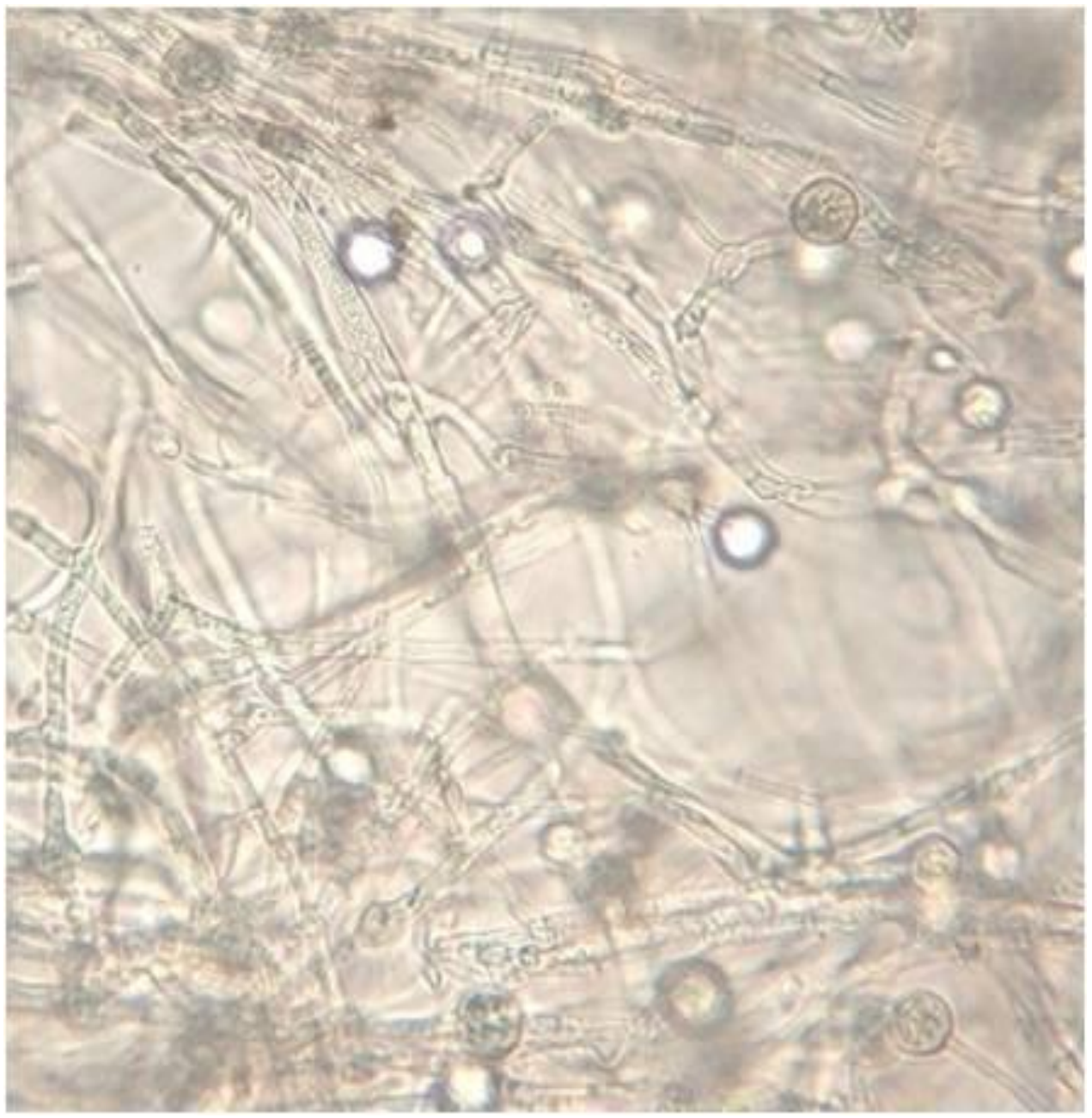


Table.1 Morphological description of Ganoderma isolates

\begin{tabular}{|c|c|c|c|c|c|c|c|c|c|c|}
\hline \multirow{2}{*}{$\begin{array}{l}\text { Sr. } \\
\text { No. }\end{array}$} & \multirow{2}{*}{$\begin{array}{c}\text { Ganoderma } \\
\text { isolates }\end{array}$} & \multicolumn{4}{|c|}{ Pileus } & \multicolumn{2}{|c|}{ Stipe } & \multicolumn{3}{|c|}{ Basidiospore } \\
\hline & & Texture & Colour & Shape & Diameter (cm) & Colour & Size $(\mathbf{c m})$ & Shape & Colour & Size $(\mu \mathrm{m})$ \\
\hline 1 & GNN-1 & $\begin{array}{l}\text { Non- } \\
\text { laccate }\end{array}$ & $\begin{array}{l}\text { Dark brown with } \\
\text { light brown margin }\end{array}$ & Auriform & $14.2 \times 8.4$ & \multicolumn{2}{|c|}{ Absent } & Ellipsoid & Brown & $9.2-9.8 \times 5.6-6.3$ \\
\hline 2 & GNN-2 & $\begin{array}{l}\text { Non- } \\
\text { laccate }\end{array}$ & Light brown & Discoid & $7.5 \times 5.8$ & $\begin{array}{l}\text { Dark } \\
\text { brown }\end{array}$ & $\begin{array}{l}5.3 \times 0.75- \\
1.2\end{array}$ & Ellipsoid & Brown & $9.3-10.7 \times 6.5-7.1$ \\
\hline 3 & GNN-3 & Laccate & Light brown & Auriform & $9.4 \times 5.2$ & $\begin{array}{l}\text { Dark } \\
\text { brown }\end{array}$ & $4.3 \times 0.6-0.8$ & Ellipsoid & Brown & $9.1-10.21 \times 5.7-7.3$ \\
\hline 4 & GND-1 & Laccate & Dark brown & Auriform & $4.5 \times 3.8$ & $\begin{array}{l}\text { Dark } \\
\text { brown }\end{array}$ & $2.2 \times 1.3$ & Ellipsoid & Brown & $8.7-10.2 \times 5.3-6.5$ \\
\hline 5 & GND-2 & Laccate & Dark brown & Auriform & $6.5 \times 4.8$ & $\begin{array}{l}\text { Dark } \\
\text { brown }\end{array}$ & $4.2 \times 1.3$ & Ellipsoid & Brown & $8.11-10.21 \times 5.6-6.2$ \\
\hline 6 & GNG-1 & Laccate & Brown & Auriform & $4.7 \times 3.5$ & Brown & $2.2 \times 1.0-1.3$ & Ellipsoid & Brown & $8.7-10.12 \times 5.7-6.3$ \\
\hline 7 & GNG-2 & Laccate & $\begin{array}{l}\text { Reddish brown with } \\
\text { whitish margins }\end{array}$ & Discoid & $22 \times 18$ & Black & $12 \times 1.5-1.62$ & Ellipsoid & Brown & $9.1-9.28 \times 4.87-5.18$ \\
\hline
\end{tabular}

Table.2 Cultural characteristics of Ganoderma isolates on Malt Extract agar (MEA)

\begin{tabular}{|c|c|c|c|c|c|c|}
\hline \multirow{2}{*}{$\begin{array}{l}\text { Sr. } \\
\text { No. }\end{array}$} & \multirow{2}{*}{$\begin{array}{l}\text { Ganoderma } \\
\text { isolates }\end{array}$} & \multicolumn{3}{|c|}{ Mycelia } & \multicolumn{2}{|c|}{ Chlamydospore } \\
\hline & & Colour & Density & Type & Shape & Position \\
\hline 1 & GNN-1 & Off white & Low & Velvety & $\begin{array}{l}\text { Elliptical to spherical, thick } \\
\text { walled }\end{array}$ & $\begin{array}{l}\text { Terminal or } \\
\text { intercalary }\end{array}$ \\
\hline 2 & GNN-2 & White & High & Cottony & $\begin{array}{l}\text { Elliptical to spherical, thick } \\
\text { walled }\end{array}$ & $\begin{array}{l}\text { Terminal or } \\
\text { intercalary }\end{array}$ \\
\hline 3 & GNN-3 & White & Low & Cottony & \multicolumn{2}{|l|}{ Absent } \\
\hline 4 & GND-1 & White & High & Cottony & $\begin{array}{l}\text { Elliptical to spherical, thick } \\
\text { walled }\end{array}$ & $\begin{array}{l}\text { Terminal or } \\
\text { intercalary }\end{array}$ \\
\hline 5 & GND-2 & Off white & Low & Velvety & \multicolumn{2}{|l|}{ Absent } \\
\hline 6 & GNG-1 & White & High & Cottony & $\begin{array}{l}\text { Elliptical to spherical, thick } \\
\text { walled }\end{array}$ & $\begin{array}{l}\text { Terminal or } \\
\text { intercalary }\end{array}$ \\
\hline 7 & GNG-2 & White & Low & Cottony & \multicolumn{2}{|l|}{ Absent } \\
\hline
\end{tabular}


Isolate GNN-2: Cotton like texture was observed on all five media with the white colour colonies. On PDA, colonies formed thinner at the center where as on TGEA denser colonies formed at the centre. On MEA, YMEA and MCM, colonies were continuous and dense in the center with dense radial margins.

Isolate GND-1: On TGEA, colonies grew radially and formed thinner zones i.e. scanty mycelial growth on petri plates whereas on rest four media colonies were continuous and formed denser zones. Colonies on all the five media had cotton like texture with white colour.

Isolate GNG-1: Colonies had cotton like texture with white colour and grew radially and formed thinner zones at center with fine rays at the margins on all the five media. Thinner zones were observed in the case of TGEA whereas less or almost nil in the case of MCM and MEA.

Among the media tested, the maximum growth was recorded in Mushroom Complete Medium (MCM) viz., $7.20 \mathrm{~cm}, 6.67 \mathrm{~cm}$, $6.63 \mathrm{~cm}$ and $5.97 \mathrm{~cm}$ in GNN-2, GNG-1, GND-1 and GNN-1, respectively on fifth day of inoculation. So, it can be concluded from the present investigation that MCM was the best for the mycelia growth of all isolates.

Out of all four isolates GNN-2 mycelia growth was significantly more which covered the petri plate earlier to all i.e. after five days of inoculation while rest isolates covered the petri plates after six days of inoculation on five different media and $7.20 \mathrm{~cm}$ on $\mathrm{MCM}$ on fifth day of inoculation. The present result supports the reports of Jayasinghe et al., (2008) who isolated eight different strains of Ganoderma using potato dextrose agar (PDA) and screened the optimal mycelia growth on ten different solid culture media. The trend of growing of Ganoderma on MCM and YMEA was similar with this result. Badalyan et al., (2015) isolated the four isolates on PDA and MEA media and found the different isolates formed phenotypically different colonies on MEA and PDA media.

\section{Acknowledgements}

We are thankful to Department of Plant Pathology, N. M. College of Agriculture, Navsari Agricultural University, Navsari for providing the facility to conduct the study.

\section{References}

Badalyan, S.M., Gharibyan, N.G., Iotti, M. and Zambonelli, A. 2015. Genetic resources and mycelial characteristics of several medicinal polypore mushrooms (Polyporales, Basidiomycetes). International Journal of Medicinal Mushroom. 17: 371-384.

Balase, T. and Tanase, C. 2012. Culture Description of Some Spontaneous Lignicolous Macromycetes Species. Journal of Plant Development. 19: 8397.

Jayasinghe, C., Imtiaj, A., Hur, H., Lee, G.W., Lee, T.S. and Lee, U.Y. 2008. Favourable culture condition for growth of Korean wild strains in Ganoderma lucidum. Mycobiology. 36: 28-33.

Kapoor, P. and Sharma, B.M. 2014. Studies on different growth parameters of Ganoderma lucidum. International Journal of Science, Environment and Technology. 3: 1515-1524.

Latiffah, Z. and Ho, Y.W. 2005. Morphological characteristics and somatic incompatibility of Ganoderma from infected oil palm from three inland estates. Malaysian Journal of Microbiology. 1: 46-52.

Nithya, M., Ambikapathy, V. and Panneerselvam, A. 2014. Collection, 
identification, phytochemical analysis and phytotoxicity test of wood inhabiting fungi Ganoderma lucidum (Curt.Fr.) P.Karst. Hygeia: Journal for drugs and medicine. 6: 31-39.

Parkash, V. and Sharma, A. 2016. In vitro efficacy of bracket fungi for their potential antimicrobial activity. Journal of microbiology, biotechnology and food sciences. 6: 818-822.

Pristas, P., Kvasnova, S., Gaperova, S., Gasparcova, T. and Gaper, J. 2017. Application of MALDI-TOF mass spectrometry for in vitro identification of wood decay polypores. Forest Pathology. 47: e12352.

Rajesh, K., Dhanasekaran, D. and Panneerselvam, A. 2014. Isolation and taxonomic characterization of medicinal mushroom Ganoderma spp. Academia Journal of Microbiology Research. 2: 61-70.

Smith, B.J. and Sivasithamparam, K. 2003. Morphological studies of Ganoderma (Ganodermataceae) from the Australasian and Pacific regions. Australian Systematic Botany. 16: 487503.

Wang, X.C., Xi, R.J., Li, Y., Wang, D.M. and Yao, Y.J. 2012. The species identity of the widely cultivated Ganoderma, 'G. lucidum' (Ling-zhi) in China. PLoS One. 7: e40857.

Woo-Sik, J., Yun-Ju, C. and Soon-Ja, S. 2009. Culture Conditions for the Mycelial Growth of Ganoderma applanatum. Mycobiology. 37: 94-102.

\section{How to cite this article:}

Anjali Suansia and Priya John. 2020. Morphological and Cultural Characteristics of Different Collections of Medicinal White-Rot Bracket Fungi Ganoderma P. Karst. Int.J.Curr.Microbiol.App.Sci. 9(01): 2636-2644. doi: https://doi.org/10.20546/ijcmas.2020.901.299 